\title{
Peningkatan Efisiensi Agribisnis Kentang melalui Introduksi Bibit Granola 4 di Desa Bandar Hinalang Kecamatan Purba Kabupaten Simalungun
}

\author{
Stefanus Deras \\ Program Studi Agribisnis, Fakultas Pertanian, Unika St. Thomas \\ Email : stefanusderas1962@gmail.com
}

\begin{abstract}
Abstrak
Perbaikan efisiensi agribisnis kentang saat ini menjadi alternatif penting tanpa harus melalui perluasan areal. Introduksi bibit kentang Granola 4 (G4) bersertifikasi dengan rekomendasi penggunaan sarana produksi dan alokasi tenaga kerja yang optimal mampu mendongkrak efisiensi agribisnis kentang pada tingkat usahatani. Tujuan kajian ini untuk membandingkan tingkat efisiensi ekonomi agribisnis kentang G4 bersertifikasi dan non sertifikasi pada tingkat usahatani dengan efisiensi yang dihitung dari rekomendasi Balai Benih Kentang. Penelitian dilakukan terhadap 5 responden petani kentang G4 bersertifikasi dan 15 petani G4 non sertifikasi. Hasil analisis menunjukkan efisiensi agribisnis kentang G4 bersertifikasi sebesar 0,31 lebih kecil dari pada efisiensi agribisnis kentang G4 non sertifikasi sebesar 0,43. Data memperlihatkan jumlah pemakaian sarana produksi dan tenaga kerja melebihi rekomendasi, berimplikasi pada berkurangnya efisiensi. Kedua angka efisiensi yang diukur dengan $\mathrm{B} / \mathrm{C}$ ratio lebih kecil daripada efisiensi agribisnis kentang $\mathrm{G} 4$ bersertifikasi dengan rekomendasi pemakaian pupuk anorganik tunggal sebesar 2,22 dan pupuk majemuk sebesar 1,998. Berdasarkan hasil penelitian disarankan efisiensi teknis produksi kentang G4 dan efisiensi harganya masih dapat ditingkatkan dengan pengalokasian penggunaan sarana produksi dan tenaga kerja sesuai rekomendasi pemakaian pupuk anorganik tunggal maupun majemuk, dengan kriteria tepat dosis, tepat waktu, tepat cara, tepat harga, dan tepat lokasi, dan mengurangi pemakaian pupuk berlebihan.
\end{abstract}

Kata kunci : kentang Granola 4, efisiensi ekonomi, R/C ratio, B/C ratio.

\begin{abstract}
Increasing the efficiency of the potato agribusiness is currently an important alternative without having to expand the area. The introduction of certified Granola $4(\mathrm{G} 4)$ potato seedlings with recommendations on the use of production facilities and optimal allocation of labor can boost the efficiency of potato agribusiness at the farm level. The purpose of this study was to compare the level of economic efficiency of G4 certified and noncertified potato agribusiness at farm level with the efficiency calculated from the recommendation of the Potato Seed Center. The study was conducted on 5 respondents of G4 certified potato farmers and 15 non-certified G4 farmers. The analysis showed that the efficiency of the G4 certified potato agribusiness was 0.31 smaller than the non-certified G4 potato agribusiness efficiency of 0.43 . The data shows that the number of uses of production facilities and labor exceeds the recommendation, which implies reduced efficiency. The two efficiency figures as measured by the B / C ratio are smaller than the efficiency of certified G4 potato agribusiness with the recommendation of using single inorganic fertilizers of 2.22 and compound fertilizers of 1.998. Based on the research results, it is suggested that the technical efficiency of G4 potato production and price efficiency can still be improved by allocating the use of production facilities and labor according to recommendations for the use of single or multiple inorganic fertilizers, with the right dosage criteria, on time, in the right way, on price, and on location. and reduce excessive fertilizer use.
\end{abstract}

Keywords : potato Granola 4, economic efficiency, $\mathrm{R}$ / C ratio, B / C ratio

\section{PENDAHULUAN}

Penanganan usahatani kentang berbasis agribisnis penting demi terciptanya keseimbangan pasar bagi semua pelaku pada sektor hulu, sektor usahatani, dan sektor hilir yang terlibat. Berbagai perusahaan yang memproduksi barang dan jasa bagi usahatani dan industri pengolahan hasil usahatani dan pemasaran hingga pengecer memiliki kepentingan yang sama yakni tersedianya produksi dalam jumlah cukup dan berkualitas, berkelajutan, dan kontinu. Komoditi kentang dapat diatur pola tanam dan waktu panennya sehingga frekuensi bulan tanam dan panen bisa lebih dari dua kali setahun.
Ada sejumlah permasalahan di bidang produksi kentang, yakni produksi tidak cukup tersedia bagi industri pengolahan maupun untuk kon-sumsi restoran, perhotelan, dan kebutuhan rumah tangga konsumen. Selama tahun 2014 s/d 2019, kon-disi produksi kentang nasional sangat bervariatip masing-masing 1.347 .815 ton pada tahun 2014, menu-run selama tahun 2015 hingga tahun 2017 masing-masing menjadi 1.219 .270 ton, 1.213 .038 ton, dan 1.164 .736 ton, dan kembali meningkat tahun 2018 menjadi 1.284.760 ton. Pusat data dan informasi (PUSDATIN) tahun 2015 menunjukkan data konsumsi kentang (kg/kapita/tahun) Indonesia 
selama tahun 2011 hingga 2015 berturut-turut sebesar 1.564, 1.4801 .5641 .476 2.294. Kebutuhan kentang dalam negeri dipenuhi oleh kentang impor jenis kentang iris beku memperlihat kan trend yang meningkat setiap tahun selama kurun waktu yang 2016 sd 2019 berturut-turut (ton) 39.068, 47.969, 52.773, dan 46.812. Selain itu jenis kentang segar impor pada selang waktu yang sama berturut-turut (ton) 40.961, 61.601, 31.787, dan 24.002 ton (Kementerian Pertanian, 25 November 2019). Impor kentang selama Januari s/d September 2016 mencapai volume 65.195.11 ton dengan nilai impor sebesar US\$ 56.168.925 (BPS, 2016). Pertumbuhan konsumsi ken-tang di Indonesia dipicu oleh perubahan gaya hidup dan bertumbuhnya kelompok konsumen kelas menengah ke atas.

Menurut Larisa (2019), meskipun kontribusi makanan beku terhadap industry makanan dan minuman masih dibawah $10 \%$, diyakini akan terus tumbuh seiring dengan berkembangnya bisnis hotel, restoran, dan catering. Menurut Stefanus Indrayana (Larisa, 2019), potensi pertumbuhan industry makanan olahan beku mengalami kenaikan termasuk untuk olahan kentang beku. Potensi tersebut didorong per-ubahan gaya hidup masyarakat dan keinginan diver-sifikasi sumber karbohidrat dalam sajian makanannya. Menurut Abdul Rochim (2019), kebutuhan kentang untuk industry biasanya menggunakan varietas Atlantik yang diimpor. Kentang segar impor akan diolah menjadi Chip atau keripik, sedangkan kentang Iris beku akan diolah menjadi French fries atau kentang goring. Impor kentang akan menurun karena kentang Atlantik sudah mulai dibudidayakan di dalam negeri. Perusahaan makanan berskala besar yang mengolah dan mengimpor kentang Atlantik kini bermitra dengan petani local untuk menanam bibit tanaman itu.

Selama kurun waktu tujuh tahun (2011-2017), hasil produksi kentang di Indonesia berfluktuasi dengan kecenderungan peningkatan, kecuali tahun 2014. Hal tersebut mungkin disebabkan oleh berbagai tantangan pengembangan kentang di dataran tinggi, seperti bersaing dengan komoditas hortikultura lain dan konservasi lahan untuk peruntukan lain (Rogi dkk, 2016). Menurut data Kementerian Pertanian (2018), produktivitas kentang Indonesia pada tahun 2017 sebesar 15,40 ton/ha. Angka produktivitas ini masih tergolong rendah apabila dibandingkan dengan pro-duktivitas kentang di negara produsen kentang lainnya di Asia, seperti Thailand dan India masing-masing mencapai 16,34 dan 22,30 ton/ha. Menurut Rochim (2019), produksi kentang Indonesia pada tahun 2018 mencapai 1,5 juta ton. Varietas kentang yang dipro-duksi dalam negeri adalah Granola atau kentang sayur.

Menurut Kasimin (2013), rendahnya produk-tivitas kentang di Indonesia disebabkan oleh rendahnya kualitas dan kuantitas benih, teknik budidaya konven-sional yang masih digunakan petani, terbatasnya daerah yang sesuai untuk budidaya kentang, serta serangan hama dan penyakit. Selain itu, modal yang cukup tinggi dan perencanaan yang baik dibutuhkan dalam kegiatan produksi benih kentang. Salah satu faktor penentu (dominan) dalam usaha peningkatan produksi kentang adalah penggunaan bibit kentang. Menurut Hidayat, 2010 (Amrullah, dkk., 2019), pemenuhan bibit kentang bersertifikat secara nasional hingga kini hanya mencapai $10 \%$, sedangkan sisanya mengguna kan bibit hasil seleksi sendiri yang berkualitas rendah. Ini berdampak pada produksi rata-rata nasional baru mencapai 12 ton per hektar dari potensi hasil 40 ton/Ha.

Penelitian ini bertujuan untuk meng-analisis perbandingan tingkat efisiensi agri-bisnis kentang Granola 4 bersertifikasi dan non sertifikasi dan dengan yang direkomendasikan pada berbagai keragaan penggunaan saprotan dan curahan kerja dalam usahatani.

\section{Kajian Teori \\ Kriteria Benih Kentang G4 Bersertifikasi}

Benih bermutu adalah benih yang mampu mengeks-presikan sifat-sifat unggul yang diwakilinya. Menurut Basuki et. al (Rogi, 2016) terdapat beberapa kelas sertifikasi benih kentang yang dirilis oleh Direktorat Perbenih-an Hortikultura, tahun 2007, yaitu: Kelas Benih G0 setara dengan Benih Penjenis (BS), Kelas Benih G1 setara dengan Benih Dasar Satu (BD1/FS1), Kelas Benih G2 setara dengan Benih Dasar 2 (BD2/FS2), Kelas Benih G3 setara dengan Benih Dasar Pokok (SS), dan Kelas Benih G4 setara dengan Benih Sebar (ES). Kelas Benih G4 ini digunakan petani untuk produksi umbi kentang. Varietas benih yang dilepas kepada petani adalah varietas Granola, yaitu salah satu varietas kentang yang dilepas oleh Balai Penelitian Tanaman Sayuran (BALITSA) periode 1980 s/d 2005, berdaya hasil tinggi, umur pendek, dan memiliki adaptasi yang luas serta toleran terhadap serangan layu bakteri. Satu-satunya varietas yang mendominasi produksi kentang di Indonesia yaitu mencapai areal tanam $90 \%$ lebih. Ada berbagai sumber asal benih ken-tang bagi petani, yakni: (1) Benih berasal dari Penangkar Benih (seed grower) dengan ciri-ciri kualitas benih terjamin, benih bebas dari virus, benih bersertifikat, benih mendapat pe-ngawasan dari Badan Pengawasan Serti-fikasi Benih Tanaman Pangan dan Horti-kultura (BPSBTPH), harga benih terjangkau, dan produksi tinggi. (2) Benih Asal Petani lain, dengan ciri-ciri harga lebih murah, mudah didapat, tahu asal usul-nya di lapangan, faktor kepercayaan, (3) Benih Sendiri, yaitu benih dari hasil seleksi sendiri dengan kualitas yang cukup baik, dengan alasan tidak ada dana untuk membeli kepada produsen benih yang lain.

Adapun kriteria mutu benih ken-tang adalah umbi sehat dan bebas virus, serta kriteria ukuran 
benih. Kesulitan bagi petani mendapat ukuran tertentu yang diinginkannya karena ketersedia-an terbatas sehingga ukuran benih umumnya jadi tidak seragam. Pada tahun 1996, Sahat et al. (Rogi, 2016), tanaman yang berasal dari umbi bibit ukuran kecil ( $<20$ gram/umbi) mengalami serangan penyakit virus dan layu bakteri lebih tinggi daripada tanaman yang berasal dari umbi bibit yang lebih besar, dan semakin besar ukuran umbi bibit yang digunakan semakin tinggi hasil yang diperoleh.

\section{Penggunaan Sarana Produksi Yang Direkomendasikan \\ Sarana produksi pupuk yang} direkomendasi-kan untuk usahatani kentang meliputi pupuk organic dan anorganik. Pupuk organik berupa pupuk kandang terdapat beberapa alternative, yakni jenis kotoran sapi 10-25 ton/ha, atau jenis kotoran ayam 15-20 ton/ha, atau kompos (bokasi) 5-10 ton/ha. Penggunaan pupuk anorganik (kimia) umumnya pupuk majemuk NPK sebanyak $350 \mathrm{~kg} / \mathrm{ha}$. Bila harus meng gunakan pupuk tunggal, produksi kentang dapat diperbaiki dengan cara penggunaan berbagai jenis pupuk anorganik dalam jumlah yang relatif banyak; misalnya, pemupukan dasar: Urea $200 \mathrm{~kg}$ per ha, SP36 200kg per ha, KCL $75 \mathrm{~kg}$ per ha, POC 1-2 botol per $1000 \mathrm{~m},{ }^{2}$ pupuk kandang 5-6 ton per ha, SP36 $250 \mathrm{~kg}$ per ha, KCL $150 \mathrm{~kg}$ per ha. Selanjutnya pemupukan susukan II diberikan setelah tanaman berumur 45 hari sbb: Urea $150 \mathrm{~kg}$ per ha dan KCL75 kg per ha. Ginting (2005), mendeskripsikan pencurahan tenaga kerja pada usahatani kentang sebesar 416.08 HKP/hektar/tahun, terdiri dari curahan tenaga kerja rata-rata dalam keluarga dan tenaga kerja luar keluarga masingmasing sebesar 50.88 HKP dan 365.20 per hektar.

\section{Konsepsi Efisiensi}

Konsep efisiensi yang digunakan dalam penelitian ini mengacu kepada efisiensi yang dikemukakan oleh Farrell (1957) dan Coelli et al. (1998). Efisiensi digolongkan menjadi tiga yaitu efisiensi teknis, efisiensi alokatif, dan efisiensi ekonomi. Efisiensi teknis memperlihatkan kemampuan relatif dari perusahaan (usahatani) untuk memperoleh output tertentu dengan menggunakan jumlah input tertentu pada tingkat teknologi tertentu. Efisiensi alokatif memperlihat-kan kemampuan relatif dari usahatani untuk menggunakan input untuk menghasilkan output pada kondisi biaya minimal atau keuntungan maksimal pada tingkat teknologi tertentu. Efisiensi alokatif bisa diperoleh pada kondisi usahatani yang efisien secara teknis. Jika efisiensi alokatif diperoleh pada kondisi efisien secara teknis usahatani tersebut berada pada kondisi efisisensi ekonomi. Farrel dalam Coelli et al. (1998) menjelaskan bahwa efisiensi terdiri dari dua komponen yaitu efisiensi teknis dan efisiepsi alokatif. Efisiensi teknis memperlihatkan kemampuan dari usahatani memperoleh output maksimal dari jumlah input tertentu. Sedangkan efisiensi alokatif memper-lihatkan kemampuan dari usahatani untuk meng-gunakan proporsi input optimal sesuai dengan harganya dan teknologi produksi yang dimilikinya. Penggabung-an keduanya akan menjadi efisiensi ekonomi.

(Mubyarto,1989) berpendapat efisiensi merupa-kan istilah yang digunakan untuk mengukur keberhasil-an usahatani. Usahatani yang produktif (efisien) berarti usahatani itu produktivitasnya tinggi. Pengertian produktivitas ini sebenarnya merupakan penggabung-an antara konsepsi efisiensi usaha (fisik) dengan kapasitas tanah. Efisiensi fisik mengukur banyaknya hasil produksi (output) yang dapat diperoleh dari satu kesatuan input; sedangkan kapasitas dari sebidang tanah ter-tentu menggambarkan kemampuan tanah itu untuk menyerap tenaga dan modal sehingga mem-berikan hasil produksi bruto yang sebesar-besarnya pada tingkatan teknologi tertentu. Jadi secara teknik, produktivitas merupakan perkalian antara efisiensi usaha (fisik) dengan kapasitas tanah.

Soekartawi (1999), suatu penggunaan factor produksi dikatakan efisiensi secara teknis (efisiensi teknis) kalau factor produksi yang dipakai menghasil kan produksi yang maksimum. Dikatakan efisiensi harga atau efisiensi alokatif kalau nilai dari produk marginal sama dengan harga factor produksi yang bersangkutan, dan dikatakan efisiensi ekonomi kalau usaha pertanian tersebut mencapai efisiensi teknis sekaligus juga mencapai efisiensi harga.

Hasil penelitian Barus (1998) meng-gunakan persamaan fungsi produksi Cobb-Douglas menyimpul-kan bahwa factor produksi luas lahan, bibit, pestisida dan pupuk berpengaruh positif terhadap produksi ken-tang, sedangkan factor produksi tenaga kerja dan pengalaman bertani berpengaruh negatif terhadap pro-duksi. Agustian dan Mayrowani (2008), menyimpul-kan bahwa kondisi riil yang terjadi dalam usahatani kentang antara lain (1) Luas areal panen komoditi kentang yang tampak berfluktuatif setiap musim berpengaruh terhadap stabilitas produksi, (2) serangan hama penyakit yang cukup beragam; dan (3) harga jual kentang jenis granola yang rendah dan relative stabil bahkan cenderung menurun, akibatnya petani melakukan pilihan jenis tanaman, sistem tanam, dan pola tanam. Secara umum terdapat dua jemis varietas kentang yang diusahakan petani di Kabupaten Bandung yaitu Kentang Granola dan Atlantik. Ginting (2005), mendeskripsikan pencurahan tenaga kerja pada usaha-tani kentang sebesar 416.08 $\mathrm{HKP} /$ hektar/tahun, terdiri dari curahan tenaga kerja rata-rata dalam keluarga dan tenaga kerja luar keluarga masing-masing sebesar 50.88 HKP dan 365.20 per hektar. Sementara itu, Deras (2007), menghitung titik pulang pokok pada usahatani kentang seluas 4000 meter kuadrat (10 rante) kasus satu sampel dan menyimpulkan bahwa angka BEP mencpai Rp.19 350.570,25, dan rasio peneri-maan 
dengan biaya (R/C Ratio) sebesar 2.35; demikian juga dengan ratio benefit cost $(\mathrm{B} / \mathrm{C}$ ratio) sebesar 1.35 sehingga dikatakan usaha-tani kentang layak untuk dijalankan.

Rendahnya produksi disebabkan oleh beberapa faktor: (1) iklim yng selalu berubah (2) bibit yang kurang baik, (3) penggunaan pupuk yang kurang bah-kan tidak sesuai kebutuhan tanaman, (4) penggunaan pestisida, dan (5) kurangnya pemeliharaan. Harga jual penting untuk merangsang produksi. Menurut Setia (2009), tinggi rendahnya harga kentang dipengaruhi oleh musim panen dan grading (pembagian mutu kentang berdasarkan kelas). Pada saat musim panen (panen raya) harga kentang akan mengalami penurunan karena jumlah pro-duksi bertambah sementara per-mintaan tetap dan sebaliknya. Grading sangat mempe-ngaruhi harga kentang, ukuran kecil kelas D (<50 gr) akan lebih tinggi disbanding kan dengan ukuran sedang kelas C (51-100 gr), ukuran sedang selanjutnya kelas B (101- 300 gr ) dan kelas A (>300 gram).

\section{METODE PENELITIAN}

Penelitian ini mau mendeksripsikan tingkat efisiensi agribisnis kentang Granola 4 bersertifikasi dengan tingkat efisiensi usahatani kentang Granola 4 non sertifikasi, lengkap dengan rekomendasi penggunaan sarana produksi yang diperlukan dalam pemakaian yang beragam. Hasil penelitian diharapkan mampu mendeskripsikan agribisnis kentang yang menghasil-kan efisiensi yang tinggi dari berbagai jenis dan volume penggunaan sarana produksi yang digunakan. Kedua kondisi efisiensi ini kemudian dibandingkan dengan tingkat efisiensi pada agribisnis kentang G4 yang direko-mendasikan oleh Balai Bibit Kentang G4 se-bagai variable control dalam penelitian ini. Variabel yang diamati adalah sarana produksi dan hasil produksi kentang Granola 4 bersertifikasi. Harga sarana pro-duksi dan harga hasil produksi pada ketiga kasus dihitung pada kondisi harga pasar yang berlaku pada saat ini (2019). Hal yang membedakan sebagai perbandingan untuk dianalisis adalah kesesuaian jenis dan volume pemakaian pupuk, juga produksi kentang antara data control dengan data yang diterapkan di daerah penelitian dengan dasar bibit kentang yang sama yakni Granola 4. Pada data pembanding (data rekomen-dasi) ada beberapa alternatif yang digunakan, yaitu penggunaan pupuk majemuk, dan pupuk tunggal. Faktor produksi yang lain seperti penggunaan tenaga kerja (jenis dan jumlahnya) dipakai data control namun dihitung dengan harga (upah) yang berlaku sekarang. Ini berarti ada empat pengukuran efisiensi, yakni: (1) efisiensi pada tingkat kasus penggunaan bibit G4 bersertifikasi, (2) efisiensi pada tingkat kasus penggunaan bibit kentang granola non sertifikasi, (3) efisiensi pada tingkat rekomendasi pengguna-an pupuk tunggal, dan (4) efisiensi pada tingkat rekomendasi penggunakan pupuk majemuk. Untuk mengukur ting-kat efisiensi agribisnis dilakukan dengan menggunakan perhitungan ekonomi yakni analisis "Revenue Cost ratio dan Benefit Cost Ratio masing-masing disingkat dengan istilah $\mathrm{R} / \mathrm{C}$ ratio dan $\mathrm{B} / \mathrm{C}$ ratio .

Populasi pada penelitian ini adalah petani yang melakukan agribisnis kentang Garonola 4 bersertifikasi dan Granola 4 non sertifikasi yang tersebar di Desa Bandar Hinalang. Besar sampel ditetapkan 5 orang petani pengusaha kentang Granola 4 bersertifikasi dan 15 petani pengusaha kentang Granola 4 non sertifikasi. Keduanya ditentukan secara sengaja (purposive sampling) tanpa mengindahkan normalitas sebaran populasi karena tidak memerlukan pengujian statistic yang menghendaki syarat normalitas data.

\section{HASIL DAN PEMBAHASAN}

Penggunaan Sarana Produksi dan Tenaga Kerja dalam Agribisnis Kentang

Sarana produksi dan tenaga kerja yang digunakan dalam agribisnis kentang terlihat relative sama dari segi jenis sarana, namun bervariasi dalam hal volume penggunaannya. Jumlah bibit Granola 4 non sertifikasi melebihi jumlah bibit G4 bersertifikasi. Volume penggunaan bibit kedua jenis granola (ser-tifikasi dan non sertifikasi) melebihi volume pada agribisnis kentang yang direkomendasikan mengguna-kan pupuk anorganik tunggal dan majemuk. Kondisi ini tentu berpengaruh terhadap produktivitas dan pen-dapatan, yang pada akhirnya berpengaruh terhadap tingkat efisiensi agribisnis kentang. Besar kecilnya volume penggunaan bibit ditentukan oleh ukuran bibit dan jarak tanam. Kebutuhan benih kentang yang direkomendasikan per ha rata-rata $1,2-1,5$ ton/ha dengan kriteria ukuran benih 30-40 gr /butir, atau 2 2,5 ton/ha jika ukuran bibit 40 gr per butir. Populasi tanaman per ha $40.000-50.000$ tanaman.

Demikian pula sarana produksi pupuk organic (kotoran ayam) yang diguna-kan dalam agribisnis kentang Granola 4 bersertifikasi memperlihatkan pemakaian yang fantastis di atas volume penggunaan pada granola non sertifikasi dan melampaui volume pada usahatani yang direkomen-dasikan menggunakan pupuk anorganik tunggal dan majemuk. Pupuk organic (ayam) yang direkomendasi-kan berkisar 15 - 20 ton dengan ratarata 17,5 ton per hektar. Penggunaan pupuk organic yang melampaui rekomendasi ini tentu mempengaruhi pertumbuhan dan produksi ken-tang. Sarana produksi pupuk majemuk NPK walaupun direkomendasikan, akan tetapi volume pemakaiannya masih jauh dari yang direkomendasikan. Ada hal yang menarik pada agribisnis kentang Granola 4 non sertifikasi adalah menggunakan pupuk tunggal jenis urea. Ketika diwawancarai ternyata karena alasan harga pupuk NPK yang tinggi menye-babkan tidak dapat memenuhi jumlah yang direkomen-dasikan. 
Alternatifnya adalah menggunakan urea tung-gal dengan harga terjangkau untuk mengimbangi kekurangan pada pupuk NPK. Penggunaan Insektisida dan fungisida relative sama pada agribisnis kentang G4 bersertifikasi dan non sertifikasi maupun yang direko-mendasikan. Volume insek-tidida dan fungisida yang sedikit mengindikasikan tidak intensifnya pengenda-lian $\mathrm{H} / \mathrm{P}$ jika dihubungkan dengan produksi kentang yang masih rendah dari yang diharapkan.

Curahan kerja pada agribisnis kentang G4 bersertifikasi juga menduduki urutan tertinggi diikuti volume curah-an kerja pada agribisnis kentang granola 4 non sertifi-kasi, dan penggunaan yang paling sedikit adalah pada agribisnis yang direkomendasikan menggunakan pu-puk anorganik tunggal dan majemuk. Kebutuhan tena-ga kerja yang direkomendasikan untuk agribisnis kentang Granola 4 sebesar 416.08 HKP/hektar/tahun. Selanjutnya kondisi yang dijelaskan di atas dapat diikuti pada Tabel 1.

Harga sarana produksi dalam agribisnis kentang Granola 4 diasumsikan sama yakni harga yang berlaku pada saat penelitian ini berlangsung. Alasannya infor-masi data pada musim tanam sebelumnya tidak tersedia lengkap. Informasi yang ada terbatas pada jenis dan volume pemakaian sarana produksi dan curahan kerja.

Oleh karena itu harga sarana produksi didicatat pada harga yang berlaku saat ini. Hasil penelitian memperlihatkan variasi jenis dan volume pemakaian sarana produksi dn curahan kerja dalam agribisnis kentang G4 sebagaimana terlihat pada Tabel 2.

Berdasarkan nilai produksi (penerimaan) dan nilai sarana dan tenaga kerja (biaya total variable) serta keuntungan dari agribisnis usahatani kentang pada varian penggunaan bibit kentang Granola, diper-oleh nilai efisiensi yang dihitung berdasarkan perban-dingan revenue cost $(\mathrm{R} / \mathrm{C}$ ratio) dan perbandingan keuntungan dengan biaya (B/C ratio) sebagaimana tertera pada Tabel 3 .

Tabel 3 memperlihatkan keragaan nilai efisiensi berdasarkan kriteria $\mathrm{R} / \mathrm{C}$ ratio maupun $\mathrm{B} / \mathrm{C}$ ratio. Kecenderungan $\mathrm{R} / \mathrm{C}$ ratio pada agribisnis kentang Granola 4 bersertifikasi justru lebih kecil secara relative dari pada agiribisnis kentang Granola 4 non sertifikasi, masing-masing 1,31 dan 1,43, atau dengan $\mathrm{B} / \mathrm{C}$ ratio masing-masing 0,31 dan 0,43. Pada agribisnis kentang Granola 4 bersertifikasi dengan $\mathrm{R} / \mathrm{C}$ ratio 1,31 mengandung pengertian bahwa setiap pengorbanan (biaya) sebesar Rp 1 akan memperoleh penerimaan sebesar Rp 1,31. Pendekatan $\mathrm{B} / \mathrm{C}$ ratio, dengan angka tersebut menggambarkan bahwa setiap $\mathrm{Rp} \quad 1$ biaya dicurahkan untuk agribisnis dalam usaha-tani kentang dapat memberi keuntungan sebesar Rp 0,31. Sebaliknya, pada agribisnis kentang Granola 4 non bersertifikasi dengan $\mathrm{R} / \mathrm{C}$ ratio 1,43 mengan-dung pengertian bahwa setiap pengorbanan (biaya) sebesar Rp 1 akan memperoleh peneri-maan sebesar Rp 1,43 .

Tabel 1. Sarana Produksi dan Tenaga Yang Digunakan dalam Agribisnis Kentang G4 Bersertifikasi, Non sertifikasi dan Rekomendasi

\begin{tabular}{|c|c|c|c|c|c|}
\hline No & Uraian & G4 Sertifika si & $\begin{array}{l}\text { G4 Non Serti } \\
\text { fikasi }\end{array}$ & R. Pupuk Tunggal & R. Pupuk Majemuk \\
\hline 1. & $\begin{array}{l}\text { Jumlah benih (ton) } \\
\text { /Ha }\end{array}$ & 1,566 & 1,794 & 1,25 ton & 1,25 ton \\
\hline \multirow[t]{5}{*}{2.} & Pupuk (ton)/Ha & & & & \\
\hline & a. Organik (Ayam) & 23.4 & 16,9 & (17,5 ton) & $15-20$ ton $(17,5$ ton $)$ \\
\hline & b. Anorga-nik: (kg) & & & & \\
\hline & NPK & $250 \mathrm{~kg}$ & $175 \mathrm{~kg}$ & 350 (ok) & 350 (ok) \\
\hline & Urea & - & $75 \mathrm{~kg}$ & - & - \\
\hline \multirow[t]{3}{*}{3.} & Pestisida (konversi) & & & & \\
\hline & a. Insekti-sida (ltr) & $32,6 *$ & $26,5 * * *$ & $\left.30,5^{*}\right)$ & $\left.30,5^{*}\right)$ \\
\hline & b. Fungisida (kg) & $23,1 * *$ & $21,2 * * * *$ & $18,52 * * * *)$ & $21,2 * * * *)$ \\
\hline 4. & $\begin{array}{ll}\text { Tenaga } & \text { Kerja } \\
(\text { HKP) }\end{array}$ & 751 & 603,5 & 416.08 & 416.08 \\
\hline 5. & Produksi (Ton) & 26,364 & 21,67 & $35,00 * * * * * *)$ & $35,00 *)$ \\
\hline
\end{tabular}

Keterangan: * Konversi ke Insektisida Curater

** Konversi ke Fungisida Daconil

*** Konversi ke Insektisida Marshal

***** Konversi ke Fungisida Curate

****** Diasumsikan produksi potensial sama, dan harga jual dihitung berdasarkan harga yang berlaku saat ini. Produktivitas nasional 15,4 ton (Tahun 2017)

Tabel 2. Nilai Sarana Produksi, Tenaga Kerja dan Nilai Produksi serta Ke Usahatani Kentang Bibit G4 Bersertifikasi dan Non sertifikasi Serta Rekomendasi

\begin{tabular}{|l|l|l|l|l|l|}
\hline No & Uraian *) & G4 Sertifikasi & $\begin{array}{l}\text { G4 Non } \\
\text { Sertifikasi }\end{array}$ & $\begin{array}{l}\text { R. Pupuk Tung- } \\
\text { gal }\end{array}$ & $\begin{array}{l}\text { R. Pupuk } \\
\text { Majemuk }\end{array}$ \\
\hline
\end{tabular}




\begin{tabular}{|l|l|l|l|l|l|}
\hline \hline No & Uraian *) & G4 Sertifikasi & $\begin{array}{l}\text { G4 Non } \\
\text { Sertifikasi }\end{array}$ & $\begin{array}{l}\text { R. Pupuk Tung- } \\
\text { gal }\end{array}$ & $\begin{array}{l}\text { R. Pupuk } \\
\text { Majemuk }\end{array}$ \\
\hline 1. & Nilai benih (Rp) $*$ & 21.924 .0001 1) & 1.794 .000 2) & 17.500 .000 & 17.500 .000 \\
\hline 2. & Nilai Pupuk (Rp) & & & & \\
\hline & a. Organik (Ayam) 3) & 11.700 .000 & 8.450 .000 & 8.750 .000 & 8.750 .000 \\
\hline & b. An-organik: ** & & & & \\
\hline & NPK 4) & 750.000 & 525.000 & 1.050 .000 & 1.050 .000 \\
\hline & Urea 5) & - & 135.000 & - & - \\
\hline 3. & $\begin{array}{l}\text { Nilai Pestisida } \\
\text { (konversi) (Rp) }\end{array}$ & & & & \\
\hline & a. Insekti-sida 6) & $6.175 .385,4$ & 4.925 .154 & $5.777 .584,5$ & $5.777 .584,5$ \\
\hline & b. Fungisida 7) & 1.293 .600 & $4.015 .894,8$ & 1.037 .120 & 1.187 .200 \\
\hline 4. & $\begin{array}{l}\text { Nilai Tenaga Kerja } \\
\text { (Rp) 8) }\end{array}$ & 75.100 .000 & 60.350 .000 & 41.608 .000 & 41.608 .000 \\
\hline 5. & $\begin{array}{l}\text { Jumlah Nilai Sarana } \\
\text { dan nilai kerja } \\
\text { (Rp)*** }\end{array}$ & $116.942 .985,4$ & $80.195 .048,8$ & $70.522 .704,5$ & $75.872 .784,5$ \\
\hline 6. & Nilai Produksi (Rp) 9) & 171.366 .000 & 140.855 .000 & 227.500 .000 & 227.500 .000 \\
\hline 7. & Keuntungan (Rp) & $54.428 .014,6$ & $60.659 .951,2$ & $156.977 .295,5$ & $151.627 .215,5$ \\
\hline
\end{tabular}

\section{Keterangan Tabel 2:}

*) Nilai = volume $\mathrm{x}$ harga per satuan

1) Harga bibit G4 bersertifikasi Rp $14.000 / \mathrm{kg}$

2) Harga bibit non bersertifikasi Rp $10.000 / \mathrm{kg}$

3) Harga pupuk kandang (ayam) Rp 500/kg

4) Harga NPK Rp $3.000 / \mathrm{kg}$

5) Harga Urea Rp Rp 1.800

6) Harga Insektisida (konversi) Rp 189.429/1tr

7) Harga Fungisida (konversi) Rp 56.000/kg
8) Upah kerja Rp 100.000/HKP

9) Harga produksi pada masa covid Rp $6.500 / \mathrm{kg}$

*) Dihitung berdasarkan Harga Eceran Tertinggi (HET) subsidi.

**) Harga bibit per biji Rp 1.750 (dalam $1 \mathrm{~kg}$ ada 8 biji bibit kentang).

***) Biaya tetap per hektar diasumsikan sama, hanya biaya variabel yang dihitung.

Tabel 3. Perbandingan Tingkat Efisiensi Agribisnis Kentang Granola Di Penelitian

\begin{tabular}{|l|l|l|l|l|l|}
\hline No & Urai-an & $\begin{array}{l}\text { Grano-la (G4) } \\
\text { Sertifi-kasi }\end{array}$ & $\begin{array}{l}\text { Grano-la Non } \\
\text { Serti-fikasi }\end{array}$ & $\begin{array}{l}\text { Reko-menda-si } \\
\text { Pupuk Tung-gal }\end{array}$ & $\begin{array}{l}\text { Reko-menda-si } \\
\text { Pupuk Maje-muk }\end{array}$ \\
\hline 1. & $\begin{array}{l}\text { Jum-lah Nilai } \\
\text { Sarana dan nilai } \\
\text { kerja (Rp/Ha) }\end{array}$ & $116.942 .985,4$ & $80.195 .048,8$ & $70.522 .704,5$ & $75.872 .784,5$ \\
\hline 2. & $\begin{array}{l}\text { Nilai Pro-duk-si } \\
\text { (Rp/ Ha) }\end{array}$ & 171.366 .000 & 140.855 .000 & 227.500 .000 & 227.500 .000 \\
\hline 3. & $\begin{array}{l}\text { Ke-untung-an } \\
\text { Rp/Ha) }\end{array}$ & $54.428 .014,6$ & $60.659 .951,2$ & $156.977 .295,5$ & $151.627 .215,5$ \\
\hline 4. & R/C ratio & 1,31 & 1,43 & 3,22 & 2,998 \\
\hline 5. & B/C ratio & 0,31 & 0,43 & 2,22 & 1,998 \\
\hline
\end{tabular}

Pendekatan $\mathrm{B} / \mathrm{C}$ ratio, angka tersebut menggambarkan bahwa setiap $\mathrm{Rp} 1$ biaya dicurahkan untuk agribisnis usahatani kentang dapat memberi keuntungan sebesar Rp 0,43. Angka R/C ratio dan $\mathrm{B} / \mathrm{C}$ ratio ditentukan oleh faktor jumlah dan harga produksi, jumlah dan harga sarana produksi, jumlah dan upah tenaga kerja. Berdasarkan variable ini terlihat dari Tabel 1 sebelum-nya, biaya produksi untuk produksi kentang bibit G4 bersertifikasi mencapai sebesar Rp 116.942.985,4 di-bandingkan dengan biaya produksi untuk kentang bibit G4 non sertifikasi hanya sebesar Rp 80.195.048,8/Ha. Besar kecilnya biaya dipengaruhi volume dan harga sarana produksi yang digunakan. Pada agribisnis ken-tang G4 bersertifikasi sarana produksi yang menyumbang biaya terbesar adalah benih $\mathrm{Rp}$ 21.924.000, pupuk kandang (Rp 11.700.000), pupuk NPK (Rp


kerja ( $R p$ 75.000). Volume pemakaian berturutturut $(\mathrm{kg})$ benih $(1.566)$, pupuk kandang (23.400), pupuk NPK $(250 \mathrm{~kg})$, insektisida $(32,6 \mathrm{ltr})$, fungisida $(23,1 \mathrm{~kg})$, dan tenaga kerja (751 HKP). Volume penggunaan sarana produksi dan tenaga kerja melampaui yang direkomen-dasikan sebagaimana terlihat pada Tabel 1.

Pemakaian sarana produksi dan tenaga kerja berlebihan tidak serta merta mendongkrak produktivitas bahkan sebaliknya bisa terjadi dapat menurunkan produksi. Dari segi produksi, memang terlihat produktivitas pada agribisnis kentang G4 bersertifikasi lebih besar (26,364 ton) daripada kentang non sertifikasi sebesar 21,67 ton. Selisih produktivitas mencapai 4,694 ton; akan tetapi, 
persoalan efisiensi tidaklah cukup dinilai dari produktivitas fisik melainkan efisiensi harga sarana produksi dan harga produksi. Pemakaian sarana pro-duksi berlebihan menyebabkan ongkos produksi men-julang tinggi sehingga efisiensi eko-nomi dari agri-bisnis kentang Granola 4 bersertifikasi menjadi kecil dibanding efisiensi pada agribisnis kentang Granola 4 non bersertifikasi.

Sebagai perbandingan dengan agribisnis yang me-rekomendasikan pemakaian pupuk tunggal dan pupuk majemuk dalam agribisnis kentang G4 bersertifikasi, diketahui dari Tabel 3 memperlihatkan nilai efisiensi ber-dasarkan kriteria $\mathrm{R} / \mathrm{C}$ ratio maupun $\mathrm{B} / \mathrm{C}$ ratio yang lebih besar dari usahatani tanpa rekomendasi pupuk tunggal dan majemuk. Angka $\mathrm{R} / \mathrm{C}$ ratio dan $\mathrm{B} / \mathrm{C}$ ratio pada kedua rekomendasi itu masing-masing 1,63 (rekomendasi pupuk tunggal) dan 1,61 (rekomendasi pupuk majemuk), atau dengan $\mathrm{B} / \mathrm{C}$ ratio masingmasing 0,63 dan 0,61. Pada agribisnis kentang Granola 4 berser-tifikasi dengan $\mathrm{R} / \mathrm{C}$ ratio 1,61 mengandung pengertian bahwa setiap pengorbanan (biaya) sebesar Rp 1 akan memperoleh pene-rimaan sebesar Rp 1,63. Pendekatan B/C ratio angka tersebut menggambarkan bahwa setiap Rp 1 biaya dicurahkan untuk agribisnis usahatani kentang dapat memberi keuntungan sebesar Rp 0,63. Angka R/C ratio dan $\mathrm{B} / \mathrm{C}$ ratio ditentukan oleh faktor jumlah dan harga produksi, jumlah dan harga sarana produksi, jumlah dan upah tenaga kerja. Berdasarkan variable ini terlihat dari Tabel 1 biaya produksi untuk produksi kentang G4 bersertifikasi dengan rekomen-dasi pupuk tunggal mencapai sebesar Rp 70.522.704,5/ Ha dan rekomendasi pemakaian pupuk majemuk sebesar RP 75.875.784,5/Ha. Besar kecilnya biaya di-pengaruhi volume dan harga sarana produksi yang di-gunakan. Pada agribisnis kentang G4 bersertifikasi dengan rekomendasi penggunaan pupuk tunggal dan pupuk majemuk semuanya terukur sehingga ongkos produksi dapat ditekan dan dengan sendirinya efisiensi dipertahankan lebih tinggi daripada penggunaan sarana produksi berlebihan. Pada akhirnya efisiensi ekonomi agribisnis kentang pada rekoemendasi pemakaian pu-puk tunggal dan pupuk majemuk lebih tinggi sebesar masing-masing 1,63 (rekomendasi pupuk tunggal) dan 1,61 (rekomendasi pupuk majemuk).

\section{KESIMPULAN}

1. Introduksi bibit kentang G4 bersertifikasi tidak serta merta meningkatkan efisiensi agribisnis tanpa menerap kan volume dan jenis sarana produksi dan curahan kerja yang direkomendasikan, dengan nilai $\mathrm{B} / \mathrm{C}$ ratio 0,31 .

2. Agribisnis kentang G4 non sertifikasi melalui pene-rapan volume dan jenis sarana produksi dan curahan kerja yang optimal memberi efisiensi 0,4 > G4 ber-sertifikasi..
3. Tingkat efisiensi agribisnis G4 bersertifikasi dan G4 non sertifikasi memiliki tingkat efisiensi yang lebih kecil dari nilai efisiensi potensial melalui rekomendasi penggunaan pupuk anorganik tunggal dan majemuk.

4. Tingkat efisiensi agribisnis G4 bersertifikasi dengan rekomendasi pupuk anorganik tunggal sebesar (B/C ratio) 2,22 > pupuk majemuk dengan $\mathrm{B} / \mathrm{C}$ ratio 1,998 .

\section{SARAN}

1. Efisiensi agribisnis kentang bibit G4 bersertifikasi dapat ditingkatkan dengan mengatur volume dan jumlah pemakaian sarana produksi dan curahan kerja sesuai rekomendasi.

2. Pupuk anorganik tunggal patut diterapkan dalam agribisnis kentang G4 asal saja jenis dan volume sarana produksi serta curahan kerja sesuai rekomendasi.

3. Perlunya petani membiasakan penggunaan bibit berukuran besar 30-35 gr/biji sesuai rekomendasi.

\section{DAFTAR PUSTAKA}

Agustian dan Mayrowani, 2008. Pola Distribusi Komo-ditas Kentang Di Kabupaten Bandung. Jurnal Ekonomi Pembangunan, Vol 9, No. 1, Juni 2008, hal 96-106. Jawa Barat.

Amrullah, M. R., Sudarsono, \& Amarillis, S. (2019). Produksi dan Budidaya Umbi Bibit Kentang (Solanum tuberosum L.) di Pangalengan, Bandung, Jawa Barat. Buletin Agrohorti, 7(1), 9399.

Barus, D., 1998. Analisis Biaya dan Pendapatan Serta. Beberapa Faktor Yang Mempengaruhi Produksi Tanaman Kentang. Skripsi. Jurusan Sosial Ekonomi Pertanian Universitas Katolik Santo Thomas Sumatera Utara. Medan.

BPS (Badan Pusat Statistik). 2016. Perkembangan Ekspor Impor Hortikultura Indonesia. Badan Statistik Perdagangan Luar Negeri.

Kementrian Perdagangan Indonesia, Jakarta.

Coelli, T.J., D.S.P. Rao, and G.E. Battese. 1998. An In-troduction to Efficiency and Productivity Ana-lysis. Kluwer Academic Publisher. Boston.

Deras, S.,2007. Analisis BEP dan B/C Ratio pada Agribisnis Usahatani Kentang Di Desa Hinalang Kecamatan Purba Kabu-paten Simalungun. Laporan Penelitian Dosen Jurusan Sosial Eko-nomi Pertanian UNIKA Santo Thomas SU. Medan.

Farrell, MA. 1957. The Measurement of Productive Efficiency. Journal of the Royal Statistical Society. Series A. CXX. Part 3. 253-290.

Ginting, A., 2005. Analisis Pencurahan Tenaga Kerja dan Pendapatan Usahatani Kentang. Skripsi. .

Kasimin, S. 2013. Keterkaitan Produk dan Pelaku dalam Pengembangan Agribisnis Hortikultura 
Unggulan di Provinsi Aceh. Jurnal Manajemen \& Agribisnis, 10(2), 117-127.

Kementerian Pertanian. 2018. Statistik Pertanian 2018. Kementerian Pertanian. Jakarta:

.....2019. Statistik Pertanian 2019. Kementerian Per-tanian. Jakarta:

Larisa Huda, 2019. Produksi Kentang Nasional. Kementerian Pertanian. Jakarta.

Mubyarto, 1989. Pengantar Ekonomi Pertanian. LP3ES. Jakarta.

Ridwan, H.K. et. al. Analisis Finansial Penggunaan Benih Kentang G4 Bersertifikat. Jurnal J. Hott. Vol. 20 No. 2, 2010.

Rogi, J. E. X., Kembuan, H. S. G., \& Rombang, J. A. (2016). Laju Tumbuh Umbi Tanaman Kentang Varietas Granola dan Supejohn di Dataran Medium dengan Pemulsaan. Jurnal Hortikultura Indonesia, 7(2), 83-90.

Rochim Abdul, 2019. Produksi Kentang Indone-sia. Direktorat Jenderal Industri Agro. Kementerian Pertanian. Jakarta.

Setiadi, 2009. Budidaya Kentang. Penebar Swadaya. Jakarta.

Soekartawi, 1999. Agribisnis. Teori dan Aplikasinya. PT. Raja Grafindo Persada. Jakarta. 